Nalar: Jurnal Peradaban dan Pemikiran Islam

Vol. 2, No. 1, Juli 2018

\title{
PERAN KONSEP DIRI TERHADAP KEDISIPLINAN SISWA
}

Ihsan $\mathrm{Mz}^{1 \mathrm{a}}$

\author{
Institut Agama Islam Negeri Palangka Raya, Kalimantan Tengah, Indonesia
}

ibsan.mz@iain-palangkaraya.ac.id

\begin{tabular}{|c|c|}
\hline \multicolumn{2}{|r|}{ Abstrak } \\
\hline History & \multirow{15}{*}{  } \\
\hline 018 & \\
\hline $\mathrm{R}$ & \\
\hline Acce & \\
\hline & \\
\hline & \\
\hline & \\
\hline & \\
\hline & \\
\hline & \\
\hline & \\
\hline & \\
\hline & \\
\hline & \\
\hline & \\
\hline
\end{tabular}

\section{Pendahuluan}

Perilaku disiplin sangat penting dibudayakan dalam kehidupan, baik individu maupun kelompok. Ajaran Islam tentang shalat, puasa, zakat, haji dan lain-lain dikaitkan dengan waktu dan teknis pelaksanaan yang sudah ditentukan mengandung pendidikan perilaku disiplin yang ampuh apabila benar-benar dilaksanakan tepat waktu dan sesuai aturan yang telah dicontohkan oleh Rasulullah Saw.

Salah satu ajaran Rasulullah Saw. kepada para orang tua sebagai pendidik pertama dan utama yang mengandung nilai kedisiplinan yang amat tinggi adalah perintah mengajari dan membiasakan anak-anaknya melaksanakan shalat sejak berusia 7 tahun. Sebagaimana yang telah ditegaskan oleh Rasulullah Saw dalam hadits beliau yang artinya: "Perintabkanlah kepada anak-anak kalian untuk (melaksanakan) shalat (lima waktu) ketika mereka bersia 7 tahun, pukullah mereka karena (meninggalkan) shalat jika mereka (telab) berusia 10 tahun, serta pisabkanlah tempat tidur mereka." (HR. Abu Daud, No. 495)

Dalam Undang-Undang Sistem Pendidikan Nasional (Sisdiknas) Bab I Pasal 1:1 dijelaskan bahwa pendidikan adalah usaha sadar dan terencana untuk mewujudkan suasana belajar dan proses pembelajaran agar peserta didik secara aktif mengembangkan potensi dirinya untuk memiliki kekuatan spritual keagamaan, pengendalian diri, kepribadian, kecerdasan, akhlak mulia serta keterampilan yang diperlukan dirinya, masyarakat, bangsa dan negara (UU Sistem Pendidikan Nasional, 2011). Upaya pembentukan kepribadian dan pengembangan potensi diri secara maksimal memerlukan proses dan kesungguhan yang optimal. 
Nalar: Jurnal Peradaban dan Pemikiran Islam

Vol. 2, No. 1, Juli 2018

Satu dari beberapa sasaran pendidikan adalah membentuk dan membina peserta didik agar mampu disiplin dalam arti taat dan patuh terhadap peraturan dan memiliki pengendalian diri. Disiplin sangatlah penting dalam proses pendidikan. Setiap sekolah pasti memiliki aturan yang harus dipatuhi oleh guru, siswa dan seluruh aparat sekolah yang ada di dalamnya. Perangkat aturan yang diberlakukan bagi guru, siswa serta aparat sekolah menjadi landasan bagi perilaku kedisiplinan di sekolah.

Setiap sekolah pasti menerapkan kedisiplinan bagi guru, siswa atau pun aparat sekolah. Namun, jika melihat realitas di lapangan, masih banyak siswa yang tidak mengikuti kedisiplinan di sekolah, bahkan seorang guru pun masih banyak yang tidak disiplin serta kurang menerapkan kedisiplinan. Banyak hal yang harus dipahami dalam kedisiplinan yang ada di sekolah, yaitu kedisiplinan bukan hanya dipatuhi dan diterapkan pada siswa akan tetapi kedisiplinan juga mesti diterapkan kepada seluruh warga sekolah beserta komponen yang ada di dalamnya. Ada beberapa contoh kedisiplinan yang diterapkan pada siswa, seperti hadir tepat waktu, mengenakan seragam, dan sebagainya. Begitu pula dengan guru serta aparat sekolah juga harus menerapkan aturan yang diberlakukan.

Ada anggapan keliru dalam melihat pemberlakuan kedisiplinan di sekolah. Di antaranya adalah anggapan siswa terhadap penerapan aturan di sekolah. Mereka menganggap bahwa aturan tersebut hanya diberlakukan bagi mereka saja. Banyak dari siswa tidak memahami pentingnya penegakan aturan yang diberlakukan terhadap mereka, sehingga para siswa merasa terbebani dan sulit mengikuti aturan-aturan yang berlaku. Jika siswa memahami akan pentingnya kedisiplinan, maka siswa tidak akan merasa berat bahkan mereka akan senang mengikuti aturan tersebut.

Dalam penerapannya, terdapat beberapa faktor yang memengaruhi perilaku disiplin. Mulai dari pengetahuan tentang aturan-aturan yang berlaku, kemauan mentaati dan mematuhi aturan-aturan yang ada, pandangan dan penilaian diri tentang penegakan aturan, dukungan teman sebaya, sampai pada tertanamnya budaya senang dan merasa tenteram apabila taat dan patuh terhadap aturan atau norma-norma yang berlaku.

Berdasarkan latar belakang masalah tersebut, maka permasalahan pokok dalam penelitian ini adalah bagaimana peran Konsep Diri terhadap Kedisiplinan Siswa di Madrasah “ABC” Yogyakarta Tahun Ajaran 2015-2016.

Dalam penelitian ini, metode yang digunakan adalah metode survei. Menurut Danim (2007), penelitian dibedakan menjadi dua jenis, yaitu penelitian survei (survey research) dan penelitian non-survei (non-survey research). Kerlinger (Sugiyono, 2010) mengatakan bahwa penelitian survei adalah penelitian yang dilakukan pada populasi baik besar maupun kecil, tetapi data yang dipelajari adalah sampel yang diambil dari populasi, sehingga dapat ditemukan kejadian yang relatif distributif dan hubungan antar variabel, baik sosiologis maupun psikologis.

Dalam penelitian ini, survei digunakan dengan maksud: Pertama, untuk memperoleh gambaran umum tentang konsep diri dan kedisiplinan siswa Madrasah "ABC" Yogyakarta. Selanjutnya, dicari hubungan antara variabel konsep diri dengan perilaku disiplin. Hasil penelitian menunjukkan tingkat signifikansi terbukti tidaknya hipotesis, bukan menerangkan sejauh mana hubungan antara variabel konsep diri dengan perilaku disiplin. Kedua, penggunaan survei cukup efisien untuk menghimpun informasi yang dapat dipercaya dengan biaya yang terjangkau. Ketiga, survei dapat menghimpun data tentang populasi yang besar dari sampel yang relatif kecil.

Populasi pada penelitian ini adalah siswa Madrasah "ABC” yang berjumlah 6 kelas, dengan jumlah keseluruhan adalah 208 siswa. Adapun teknik sampling dalam penelitian ini adalah dengan menggunakan Cluster Random Sampling. Peneliti menentukan subjek 
Nalar: Jurnal Peradaban dan Pemikiran Islam

Vol. 2, No. 1, Juli 2018

penelitian berasal dari seluruh siswa kelas X dan kelas XI sebagai kelas try out, jumlah kelas try out adalah 50 siswa. Adapun jumlah siswa kelas X Madrasah "ABC" Yogyakarta tahun 2015-2016 sebagai berikut:

Tabel 1. Jumlah Siswa Kelas X

\begin{tabular}{ccc}
\hline KELAS & Laki-laki & JUMLAH \\
\hline X A & 41 & \\
X B & 35 & \\
X C & 35 & \\
X D & 29 & \\
X E & 33 & \\
X F & 35 & \\
\hline JUM AH & & 208 \\
\hline
\end{tabular}

Dari total siswa yang berjumlah 208 orang, pada saat peneliti menyebar skala ukur, tidak semua siswa hadir. Skala ukur yang berhasil dikumpulkan kembali sebanyak 195. Berdasarkan hal tersebut, maka peneliti tetap melanjutkan ke tahap selanjutnya dengan jumlah siswa yang ada.

Jenis data yang digunakan dalam penelitian ini adalah data kuantitatif. Sementara metode yang digunakan dalam pengambilan data penelitian adalah skala. Adapun skala yang digunakan dalam penelitian ini adalah Skala Kedisiplinan dan Skala Konsep Diri, dimana skala yang digunakan adalah skala tertutup, yaitu skala (kuesioner) yang disusun dengan menyediakan pilihan jawaban lengkap sehingga subjek cukup memberi tanda pada jawaban yang dipilih (sesuai).

Model skala yang digunakan adalah Skala Likert, dengan alternatif empat jawaban, yaitu (SS) sangat sesuai, (S) sesuai, (TS) tidak sesuai, (STS) sangat tidak sesuai. Pada item Favorable jawaban sangat sesuai (SS) diberi skor 4, sesuai (S) diberi skor 3, (TS) tidak sesuai diberi skor 2, (STS) sangat tidak sesuai diberi skor 1. Sementara pada jawaban Unfavorable sangat sesuai (SS) diberi skor 1, sesuai (S) diberi skor 2, (TS) tidak sesuai diberi skor 3, dan (STS) sangat tidak sesuai diberi skor 4.

\section{Kedisiplinan}

Secara bahasa, kata "disiplin" berasal dari bahasa latin, yaitu Discere yang berarti belajar. Dari kata tersebut timbul kata Disciplina yang memiliki arti pengajaran atau pelatihan. Saat ini kata disiplin mengalami perkembangan makna dalam beberapa pengertian. Pertama, disiplin berarti kepatuhan terhadap peraturan atau tunduk pada pengawasan, dan pengendalian. Kedua, disiplin sebagai latihan yang bertujuan untuk mengembangkan diri agar dapat berperilaku tertib.

Penerapan disiplin yang baik dan kuat dalam proses pendidikan akan menghasilkan mental, watak dan kepribadian yang kuat. Di sekolah anak didik belajar disiplin, seperti dalam belajar membaca, belajar mencintai buku, dan belajar bagaimana caranya belajar. Semua ini akan berhasil apabila guru dapat mendisiplinkan diri. (Yamin dan Ansari, 2008)

Kohlberg (Widodo, 2013) menyatakan bahwa perilaku disiplin akan lebih mudah tumbuh dan berkembang bila muncul dari kesadaran dalam diri seseorang. Bernhardt (Widodo, 2013) melihat kedisiplinan sebagai sesuatu yang positif, yaitu (1) melatih, bukan mengoreksi, (2) membimbing, dan bukan menghukum, (3) mengatur kondisi belajar, dan bukan hanya menghalangi dan melarang. Disiplin yang berarti positif cenderung bersifat membimbing dan menciptakan situasi serta kondisi yang mendorong pertumbuhan dan 
Nalar: Jurnal Peradaban dan Pemikiran Islam

Vol. 2, No. 1, Juli 2018

prestasi siswa. Keadaan yang demikian akan membuat siswa bersikap patuh dengan senang hati, sehingga mendorong tumbuhnya kesadaran terhadap disiplin.

\section{Faktor-faktor Yang Mempengaruhi Kedisiplinan}

Sikap disiplin akan terwujud jika disiplin ditanamkan secara serentak di semua lingkungan kehidupan masyarakat, termasuk dalam lingkungan pendidikan, pekerjaan, bahkan pada level bangsa dan negara. Penanaman disiplin harus berlanjut dengan pemeliharaan disiplin dan pembinaan terus menerus, karena disiplin sebagai sikap mental dapat berubah dan dapat dipengaruhi oleh lingkungan sekitar (Shadily, 1980).

Faktor-faktor yang mempengaruhi terciptanya disiplin sekolah adalah pertama, Faktor Internal. Faktor ini merupakan elemen yang berasal dari dalam sekolah itu sendiri, baik dari kepala sekolah, guru, karyawan dan siswa. Kedisiplinan yang dipengaruhi faktor internal ini meliputi: (1) Minat, adalah kesediaan jiwa yang sifatnya aktif untuk menerima sesuatu dari luar (Poerbakawatja, 1982). Seorang guru atau siswa yang memiliki perhatian yang cukup dan kesadaran yang baik terhadap aturan-aturan yang ditetapkan sekolah akan berpengaruh terhadap kesadaran mereka dalam melakukan perilaku disiplin di sekolah. (2) Emosi, adalah suatu keadaan yang mempengaruhi dan menyertai penyesuaian di dalam diri secara umum, keadaan yang merupakan penggerak mental dan fisik bagi individu dan dapat dilihat melalui tingkah laku luar (Crow \& Crow, 1984).

Emosi merupakan warna afektif yang menyertai sikap keadaan atau perilaku individu. Pengertian warna afektif adalah perasaan-perasaan tertentu yang dialami seseorang pada saat menghadapi suatu situasi tertentu. Contohnya: gembira, bahagia, putus asa, terkejut, benci dan sebagainya (Yusuf, 2000). Daradjat menyatakan bahwa sesungguhnya emosi memegang peranan penting dalam sikap dan tindak agama. Tidak ada satu sikap atau tindak agama seseorang yang dapat dipahami, tanpa mengindahkan emosinya (Daradjat, 1982). Emosi memiliki peran penentu terhadap kedisiplinan di sekolah. Karena emosi menggerakkan rasa kepedulian guru dan siswa atau komponen sekolah lainnya dalam menaati peraturan yang telah ditetapkan di sekolah.

Kedua, faktor eksternal. Faktor ini memiliki ruang lingkup yang lebih luas dalam mempengaruhi kedisiplinan di sekolah. Faktor ini meliputi: (1) Sanksi dan hukuman. Menurut Kartono, bahwa "hukuman adalah perbuatan yang secara intensional diberikan sehingga menyebabkan penderitaan lahir batin diarahkan untuk membuka hati nurani dan penyadaran si penderita akan kesalahannya" (Kartono, 1992). Fungsi hukuman dalam pendidikan sebagai alat untuk memberikan sanksi kepada guru, siswa dan komponen sekolah lainnya terhadap pelanggaran yang telah dilakukan, sehingga sanksi atau hukuman ini adalah sebagai bentuk penyadaran. Hal ini sebagaimana diungkapkan oleh Arikunto dengan teori sistem motivasi yaitu teori yang mengatakan bahwa: "Jika individu mendapat hukuman, maka akan terjadi perubahan dalam sistem motivasi dalam diri individu. Perubahan yang terjadi dalam sistem motivasi tersebut mengakibatkan penurunan pada individu untuk mengulangi atau menurunkan frekuensi perilaku dan tindakan yang berhubungan dengan timbulnya hukuman yang bersangkutan" (Arikunto, 1993).

Faktor eksternal berikutnya yaitu, (2) Situasi dan kondisi sekolah. Rakhmat (2004) menyatakan bahwa faktor situasional sangat berpengaruh pada pembentukan perilaku manusia seperti faktor ekologis, faktor rancangan dan arsitektural, faktor temporal, suasana perilaku dan faktor sosial. Tetapi manusia memberikan reaksi yang berbeda-beda terhadap situasi yang dihadapinya sesuai dengan karakteristik personal yang dimilikinya. Perilaku manusia memang merupakan hasil interaksi yang menarik antara keunikan individu dengan keunikan situasional (Rakhmat, 2004). 
Nalar: Jurnal Peradaban dan Pemikiran Islam

Vol. 2, No. 1, Juli 2018

\section{Aspek-aspek Disiplin}

Menurut Prijodarminto (1994) ada 3 aspek besar dalam disiplin yaitu: Pertama, sikap mental (mental attitude) yang merupakan sikap taat dan tertib sebagai hasil atau pengembangan dan latihan pengendalian pikiran dan pengendalian watak. Kedua, pemahaman yang baik mengenai sistem atau perilaku, norma, kriteria, dan standar yang sedemikian rupa sehingga pemahaman tersebut memberikan pengertian yang mendalam atau kesadaran, bahwa ketaatan akan norma, aturan, kriteria dan standar tadi merupakan syarat mutlak untuk mencapai keberhasilan. Ketiga, sikap kelakuan secara wajar menunjukkan kesungguhan hati, untuk mentaati segala hal secara cermat dan tertib.

Perilaku disiplin lahir, tumbuh dan berkembang dari sikap seseorang pada sistem nilai budaya yang telah ada didalam masyarakat. Ada unsur yang membentuk disiplin yaitu sikap yang telah ada pada diri manusia dan sistem nilai budaya yang terdapat dalam masyarakat. Disiplin akan tumbuh dan dapat dibina melalui pendidikan, penanaman kebiasaan dengan keteladanan-keteladanan tertentu. Disiplin akan mudah ditegakkan bila muncul dari kesadaran diri, peraturan yang ada dirasakan sebagai sesuatu yang memang seharusnya dipatuhi secara sadar untuk kebaikan dirinya dan sesama, sehingga akan menjadi suatu kebiasaan yang baik menuju arah disiplin diri.

\section{Konsep Diri}

Konsep diri menurut Hurlock (2005) adalah gambaran yang dimiliki orang tentang dirinya. Konsep diri ini merupakan gabungan dari keyakinan yang dimiliki orang tentang diri mereka sendiri seperti, karakteristik fisik, psikologis, sosial, emosional, aspirasi, dan prestasi. Menurut Rini (2002) konsep diri dapat didefinisikan sebagai keyakinan, pandangan dan penilaian seseorang terhadap dirinya. Seseorang dikatakan memiliki konsep diri negatif jika ia meyakini dan memandang bahwa dirinya lemah, tidak berdaya, tidak dapat berbuat apaapa, tidak kompeten, gagal, tidak menarik, tidak dapat dan kehilangan daya tarik terhadap hidup. Sebaliknya seseorang dengan konsep diri positif akan terlihat lebih optimis, percaya diri, dan selalu bersikap positif terhadap segala sesuatu.

Berdasarkan pendapat di atas, dapat disimpulkan bahwa konsep diri adalah pandangan atau persepsi dan penilaian seseorang tentang dirinya sendiri baik dari sisi fisik, sosial, maupun psikologis. Dengan konsep diri yang positif seseorang akan berupaya untuk mencapai keinginan yang optimal serta berusaha sungguh-sungguh merealisasikan keinginan atau tujuan hidupnya.

\section{Pembentukan Konsep Diri}

Konsep diri mulai berkembang sejak bayi dan akan terus berkembang sejalan dengan perkembangan individu itu sendiri. Konsep diri individu terbentuk melalui imaginasi individu tentang respon yang diberikan orang lain. Sobur (2009) mengatakan bahwa konsep diri terbentuk berdasarkan persepsi seseorang tentang sikap orang lain terhadap dirinya.

Seorang anak mulai belajar berpikir dan merasakan dirinya seperti apa yang telah ditentukan oleh orang lain dalam lingkungannya. Misalnya melalui orangtuanya, guru, atau teman-temannya. Sehingga apabila seorang guru mengatakan secara terus menerus pada seorang muridnya bahwa ia kurang mampu, maka lama kelamaan anak tersebut akan mempunyai konsep diri yang selalu merasa kurang mampu dalam melakukan suatu perintah atau instruksi.

Konsep diri terbentuk melalui reaksi yang datang dari orang-orang yang dekat atau berarti bagi individu. Cara seseorang meningkatkan konsep dirinya adalah dengan cara 
Nalar: Jurnal Peradaban dan Pemikiran Islam

Vol. 2, No. 1, Juli 2018

mengarahkan tingkah lakunya sedemikian rupa sehingga menimbulkan reaksi yang positif dari orang-orang yang dekat dengan individu itu.

Pola pembentukan konsep diri seseorang pada dasarnya terbentuk melalui proses belajar dalam interaksinya dengan lingkungan sosial. Dalam masa perubahan yang diawali dengan perubahan fisik, seperti perasaan aneh dan berbeda dengan orang lain menimbulkan perasaan tidak puas terhadap diri sendiri yang menunjukkan bahwa individu tersebut menolak keadaan dirinya sendiri. Keadaan inilah yang memengaruhi pembentukan dasar konsep diri pada individu. Keadaan konflik yang dialami individu merupakan situasi yang memungkinkan individu menunjukkan bagaimana konsep dirinya. Dengan kata lain, individu berusaha untuk menemukan dirinya sendiri serta mencoba-coba hal yang baru agar bisa menemukan identitas diri yang sebenarnya. Apabila individu tidak mendapat kesempatan untuk mengembangkan diri dan menyesuaikan diri dengan tugas-tugas perkembangan seperti inividu lain pada umumnya maka ia akan kehilangan kesempatan untuk mengembangkan konsep dirinya (Hurlock, 1997).

Hurlock (1997) mengemukakan dua tingkatan konsep diri dengan ciri sebagai berikut: (1) Konsep diri positif. Individu mengembangkan sifat-sifat seperti percaya diri, menghargai diri sendiri dan kemampuan untuk melihat dirinya secara realistis. Kemudian menilai hubungan orang lain secara tepat dan ini menumbuhkan penyesuaian pribadi dan sosial yang baik. (2) Konsep diri negatif. Individu akan mengembangkan perasaan tidak mampu dan rendah diri. Merasa ragu dan kurang percaya diri, hal ini akan menimbulkan penyesuaian pribadi dan sosial yang buruk.

Berdasarkan uraian di atas, maka dapat dipahami bahwa pembentukan konsep diri terus berkembang sejalan dengan perkembangan individu. Proses pola pembentukkan konsep diri sendiri dipengaruhi oleh penerimaan orang lain terhadap dirinya serta proses belajar dalam interaksinya dalam lingkungan sosial di sekitarnya. Cara seseorang meningkatkan konsep dirinya adalah dengan mengarahkan tingkah lakunya sedemikian rupa sehingga menimbulkan reaksi yang positif dari orang-orang di sekitarnya dan mereka dapat berpikir lebih positif tentang diri mereka.

\section{Aspek-aspek Konsep Diri}

Fitts (1965) mengemukakan bahwa konsep diri merupakan cara seseorang menilai diri sendiri yang memandang aspek-aspek: (1) Physical self, bagaimana seseorang memandang kesehatan, penampilan, kelebihan, dan kekurangan secara fisik. (2) Personal self, bagaimana seseorang memandang dan menilai keberadaaan diri sendiri. (3) Family self, bagaimana seseorang memandang dirinya dalam hubungan dengan orang-orang yang sangat dekat dengan dirinya. (4) Social self, bagaimana seseorang memandang dirinya dalam hubungan dengan orang lain. (5) Moral ethical self, bagaimana gambaran seseorang terhadap hubungannya dengan tuhan dan peraturan-peraturan atau norma-norma hidup yang berlaku.

Dari pendapat ahli di atas, maka dapat disimpulkan bahwa aspek-aspek yang memengaruhi konsep diri seseorang adalah bagaimana seseorang mengamati dirinya sendiri. Lalu bagaimana seseorang berpikir tentang dirinya sendiri. Kemudian bagaimana seseorang menilai dirinya sendiri. Selanjutnya bagaimana seseorang berusaha-dengan berbagai cara - untuk menyempurnakan dan mempertahankan dirinya dalam aspek, physical self, personal self, family self, social self, dan moral ethical self. 
Nalar: Jurnal Peradaban dan Pemikiran Islam

Vol. 2, No. 1, Juli 2018

\section{Hasil dan Pembahasan}

\section{Analisis Deskriptif}

Analisis deskriptif dengan menggunakan SPSS 21 for Windows telah menunjukkan skor Minimum, skor Maximum, Mean, dan Standar Deviasi dari masing-masing variabel. Tabel di bawah ini merupakan hasil penghitungan komputasi, sebagai berikut:

Tabel 2. Hasil Deskripsi Statistik

\begin{tabular}{lccccc}
\hline & N & Minimum & Maximum & Mean & Std. Deviation \\
\hline Konsep Diri & 195 & 66.00 & 118.00 & 94.1692 & 8.88918 \\
Kedisiplinan & 195 & 66.00 & 124.00 & 95.3641 & 10.79116 \\
Valid N (listwise) & 195 & & & & \\
\hline
\end{tabular}

\section{Deskripsi Kedisiplinan}

Berdasar Tabel 2 diperoleh hasil untuk variabel Kedisiplinan dengan skor Minimum sebesar 66,00 dan skor Maksimum 124,00. Mean sebesar 95,3641 dan Standar Deviasi sebesar 10,79116 .

Selanjutnya data variabel Kedisiplinan yang diperoleh dikategorisasikan menjadi tinggi, sedang, dan rendah, dengan menggunakan konsep kurva normal. Di bawah ini ditampilkan tabel hasil perhitungan data Kedisiplinan sebagai berikut:

\section{Tabel 3. Kategorisasi Kedisiplinan}

\begin{tabular}{cccccc}
\hline & & Frequency & Percent & Valid Percent & Cumulative Percent \\
\hline \multirow{6}{*}{ Valid } & Tinggi & 30 & 15.4 & 15.4 & 15.4 \\
& Sedang & 136 & 69.7 & 69.7 & 85.1 \\
& Rendah & 29 & 14.9 & 14.9 & 100.0 \\
& Total & 195 & 100.0 & 100.0 & \\
\hline
\end{tabular}

Dari tabel di atas dapat diketahui bahwa dari 195 siswa terdapat 30 siswa atau sebanyak 15,4\% yang mempunyai Kedisiplinan tinggi, 136 siswa atau 69,7\% yang mempunyai Kedisiplinan sedang dan 29 siswa atau 14,9\% yang mempunyai Kedisiplinan rendah.

Berdasarkan hasil di atas, dapat diketahui tingkat Kedisiplinan yang tertinggi ada pada kategori sedang, maka siswa di Madrasah "ABC” Yogyakarta kelas X Tahun Ajaran 20152016 rata-rata mempunyai tingkat Kedisiplinan yang sedang. Hal ini ditunjukkan dengan skor $69,7 \%$ sebagai skor tertinggi dan lebih besar dibandingkan dengan dua kategori lainnya, yang masing-masing mendapat 15,4\% untuk kategori tinggi dan 14,9\% untuk kategori rendah.

\section{Deskripsi Konsep Diri}

Berdasar Tabel 2 diperoleh hasil untuk variabel Konsep Diri dengan skor Minimum sebesar 66,00 dan skor Maksimum 118,00. Mean sebesar 94,1692 dan Standar Deviasi sebesar 8,88918 .

Selanjutnya data variabel Konsep Diri yang diperoleh dikategorisasikan menjadi tinggi, sedang, dan rendah, dengan menggunakan konsep kurva normal. Di bawah ini ditampilkan tabel hasil perhitungan data Konsep Diri sebagai berikut: 
Nalar: Jurnal Peradaban dan Pemikiran Islam

Vol. 2, No. 1, Juli 2018

Tabel 4. Kategorisasi Konsep Diri

\begin{tabular}{cccccc}
\hline & & Frequency & Percent & Valid Percent & Cumulative Percent \\
\hline \multirow{2}{*}{ Valid } & Tinggi & 29 & 14.9 & 14.9 & 14.9 \\
& Sedang & 136 & 69.7 & 69.7 & 84.6 \\
& Rendah & 30 & 15.4 & 15.4 & 100.0 \\
& Total & 195 & 100.0 & 100.0 & \\
\hline
\end{tabular}

Dari tabel di atas dapat diketahui bahwa dari 195 siswa terdapat 29 siswa atau sebanyak 14,9\% yang mempunyai Konsep Diri tinggi, 136 siswa atau 69,7\% yang mempunyai Konsep Diri sedang dan 30 siswa atau 15,4\% yang mempunyai Konsep Diri rendah.

Berdasarkan hasil di atas, dapat diketahui level Konsep Diri yang tertinggi ada pada kategori sedang, maka siswa di Madrasah “ABC” Yogyakarta kelas X Tahun Ajaran 20152016 rata-rata mempunyai Konsep Diri yang sedang. Hal ini ditunjukkan dengan skor 69,7\% sebagai skor tertinggi dan lebih besar dibandingkan dengan dua kategori lainnya, yang masing-masing mendapat 14,9\% untuk kategori tinggi dan 15,4\% untuk kategori rendah.

Berdasarkan analisis yang dilakukan terhadap hasil penelitian, menunjukkan bahwa Konsep Diri memiliki pengaruh yang signifikan terhadap Kedisiplinan. Semakin tinggi Konsep Diri, maka akan semakin tinggi pula Kedisiplinan. Sebaliknya, jika Konsep Diri rendah, maka semakin rendah pula Kedisiplinan.

\section{Uji Asumsi Linieritas}

Tujuan dilakukannya uji linieritas adalah untuk mengetahui apakah ada hubungan yang linier antara dua variabel atau lebih yang bersifat signifikan atau tidak. Uji ini dilakukan sebagai prasyarat dalam analisis korelasi atau regresi linier, seperti pada penelitian yang dilangsungkan ini. Pengujian menggunakan software SPSS dengan menggunakan Test for Linearity pada taraf signifikansi 0,05 . Dua variabel dikatakan mempunyai hubungan yang linier apabila signifikansi (linearity) kurang dari 0,05. Berdasarkan analisis didapatkan hasil sebagai berikut:

Tabel 5. Hasil Uji Linieritas Antara Kedisiplinan dengan Konsep Diri

\begin{tabular}{|c|c|c|c|c|c|c|c|}
\hline & & & $\begin{array}{l}\text { Sum of } \\
\text { Squares }\end{array}$ & df & $\begin{array}{l}\text { Mean } \\
\text { Square }\end{array}$ & $\mathrm{F}$ & Sig. \\
\hline \multirow{5}{*}{$\begin{array}{l}\text { KonsepDiri* } \\
\text { Kedisiplinan }\end{array}$} & \multicolumn{2}{|c|}{ Between (Combined) } & 9685.263 & 47 & 206.069 & 5.367 & .000 \\
\hline & \multirow[t]{2}{*}{ Groups } & Linearity & 7178.910 & 1 & 7178.910 & 186.972 & .000 \\
\hline & & $\begin{array}{l}\text { Deviation } \\
\text { from Linearity }\end{array}$ & 2506.353 & 46 & 54.486 & 1.419 & .061 \\
\hline & \multicolumn{2}{|c|}{ Within Groups } & 5644.152 & 147 & 38.396 & & \\
\hline & \multicolumn{2}{|l|}{ Total } & 15329.415 & 194 & & & \\
\hline
\end{tabular}

Berdasarkan Tabel 5 di atas, hasil analisis menunjukkan bahwa nilai $\mathrm{F}$ yang ditemukan adalah sebesar 186,972 dengan Sig. 0,000. Oleh karena nilai Sig tersebut kurang dari 0,05, maka dapat disimpulkan bahwa hubungan antara variabel Konsep Diri dengan Kedisiplinan bersifat linier. 
Nalar: Jurnal Peradaban dan Pemikiran Islam

Vol. 2, No. 1, Juli 2018

\section{Hubungan Antara Konsep Diri dengan Kedisiplinan}

Mengamati hasil perhitungan data hubungan antara Konsep Diri dan Kedisiplinan yang dilakukan dalam penelitian ini, ditemukan bahwa ada hubungan yang positif antara dua variabel tersebut. Dengan kata lain, jika skor Konsep Diri siswa Madrasah "ABC" Yogyakarta tinggi, maka tinggi pula tingkat Kedisiplinan mereka. Sebaliknya, jika Konsep Diri siswa rendah, maka tingkat Kedisiplinan pun juga rendah.

Menilik kembali apa yang telah disampaikan Kohlberg (dalam Widodo, 2013) bahwa perilaku disiplin seseorang akan mudah tumbuh dan berkembang dengan baik apabila kesadaran tersebut muncul dari dalam diri seseorang. Menurut Hurlock (2005), konsep diri adalah gambaran yang dimiliki seseorang tentang dirinya. Konsep diri merupakan akumulasi dari keyakinan seseorang tentang dirinya yang meliputi karakter fisik, psikologis, emosional, sosial, prestasi dan aspirasi. Karenanya, konsep diri sangat terkait dengan kesadaran diri seseorang. Sementara itu, perilaku disiplin akan berkembang secara positif jika didukung dengan kesadaran diri yang juga positif.

Siswa yang memiliki Konsep Diri yang baik akan memandang keberadaan dirinya secara positif. Siswa akan merasa percaya diri, motivasi belajarnya tinggi, akan mencoba untuk menyelesaikan setiap tugas walau terasa sulit, tetap optimis walau mengalami kegagalan, dan merasa terdorong untuk mengatur, merencanakan, memonitor, mengevaluasi bahkan memanfaatkan lingkungan untuk mendukung aktifitas belajarnya.

Gunawan (dalam Aikesari, 2008) menyatakan bahwa seseorang yang mempunyai Konsep Diri yang baik (positif) akan menjadi individu yang mampu memandang dirinya secara positif, percaya diri, selalu optimis, berani mencoba hal-hal yang baru, berani mengambil resiko, dan antusias menetapkan arah tujuan hidupnya. Dengan keadaan seperti itu tidak akan membuat seseorang menjadi pesimis dalam membentuk karakter dirinya menjadi pribadi yang memiliki disiplin tinggi. Karena mereka berani mencoba sesuatu hal yang baru, berani mengambil resiko dan menanggung segala konsekuensi yang timbul dari tindakan yang mereka lakukan.

Hasil analisis secara persial antara variabel Konsep Diri dengan Kedisiplinan diperoleh nilai $\mathrm{b} 1=0,674$ dengan $\mathrm{t}=8,346$ dan Sig. $=0,000$. Oleh karena nilai Sig. $<0,05$ $(0,000<0,05)$, maka Ho ditolak dan Ha diterima yang artinya secara parsial variabel Konsep Diri (X) berpengaruh secara signifikan terhadap Kedisiplinan (Y). Hal ini menunjukkan bahwa Konsep Diri mempunyai peran positif terhadap Kedisiplinan. Semakin tinggi Konsep Diri, maka akan semakin tinggi pula Kedisiplinan. Sebaliknya, semakin rendah Konsep Diri, maka akan semakin rendah pula Kedisiplinan.

\section{Kesimpulan}

Berdasarkan hasil analisa data dan pembahasan dalam penelitian ini, disimpulkan bahwa terdapat hubungan yang positif antara Konsep Diri dengan Kedisiplinan. Fakta ini sekaligus menunjukkan bahwa Konsep Diri yang positif dari seseorang mampu memberikan pengaruh yang juga positif terhadap Kedisiplinan. Semakin tinggi Konsep Diri siswa, maka akan semakin tinggi pula Kedisiplinannya. Sebaliknya, semakin rendah Konsep Diri, maka akan semakin rendah pula Kedisiplinan.

Berdasarkan kesimpulan di atas, peneliti menyarankan kepada siswa agar mengembangkan Konsep Diri untuk meningkatkan Kedisiplinan pada diri mereka. Sebab dengan begitu, para siswa di sekolah akan mentaati segala aturan dengan baik. Sementara saran peneliti bagi orangtua siswa, agar mereka berperan aktif dalam meningkatkan Konsep Diri siswa dengan memberikan pendidikan yang baik kepada anak-anak mereka selama 
Nalar: Jurnal Peradaban dan Pemikiran Islam Vol. 2, No. 1, Juli 2018

berada di rumah. Kepada guru, hendaknya menjadi figur yang mampu dicontoh oleh para siswa, mampu menciptakan suasana belajar yang menarik agar memberikan pendampingan dan arahan kepada siswa yang memiliki Konsep Diri rendah. Dengan peran dan kontribusi yang diberikan oleh guru diharapkan dapat memberikan pengaruh yang positif-signifikan, dimana Kedisiplinan siswa bisa lebih meningkat secara drastis. 
Nalar: Jurnal Peradaban dan Pemikiran Islam

Vol. 2, No. 1, Juli 2018

\section{DAFTAR PUSTAKA}

Arikunto, Suharsimi. 1993. Manajemen Pengajaran Secara Manusiawi. Jakarta: Rineka Cipta.

Crow, Lester D. \& Crow, Alice. 1984. Psikologi Pendidikan. Surabaya: Bina Ilmu.

Danim, Sudarwan. 2007. Visi Baru Manajemen Sekolah. Jakarta: Bumi Aksara.

Daradjat, Zakiah. 1982. Pendidikan Agama dalam Pembinaan Mental. Jakarta: Bulan Bintang.

Fitts, William H. 1965. Tennessee Self-Concept Scale Manual. Nashville, TN: Counselor

Recordings and Tests.

Hurlock, Elizabeth B. 1997. Developmental Psycology A Life Span Approach Fifth edition.

2005. Child Development, Meitasari Tjandrasa (Penterjemah), Perkembangan Anak. Jilid 2. Jakarta: Erlangga.

Kartono, Kartini. 1992. Pengantar Ilmu Mendidik Teoritis; Apakah Pendidikan Masih Diperlukan. Bandung: CV. Mandar Maju.

Prijodarminto. 1994. Disiplin Kiat Menuju Sukses. Jakarta: PT. Pradnya Paramita.

Rakhmat, Jalaluddin. 2004. Psikologi Agama Suatu Pengantar. Bandung: Mizan.

Republik Indonesia. 2011. Undang-Undang RI No. 20 Tabun 2003 tentang Sistem Pendidikan Nasional. Jakarta: Sekretariat Negara.

Shadily, Hasan. 1980. Ensiklopedia Indonesia. Jilid 5. Jakarta: Ichtiar Baru-Van Hoeve.

Sobur, Alex. 2009. Psikologi Umum. Bandung: Pustaka Setia Bandung.

Sugiyono. 2010. Metode Penelitian Pendidikan (Pendekatan Kuantitatif, Kualitatif, dan R\&D). Bandung: Alfabeta.

Widodo, Bernardus. 2013. Perilaku Disiplin Siswa Ditinjau Dari Aspek Pengendalian Diri

(Self Control) Dan Keterbukaan Diri (Self Disclosure) Pada Siswa SMK Wonoasri

Caruban Kabupaten Madiun. Skripsi Fakultas Keguruan dan Ilmu Pendidikan

Universitas Katolik Widya Mandala, Madiun.

Yamin dan Ansari. 2008. Taktik Mengembangkan Individual Siswa. Jakarta: Putra Grafika.

Yusuf, Syamsu. 2000. Psikologi Perkembangan Anak dan Remaja. Bandung: Remaja Rosdakarya.

Aikesari. 2008. Konsep Diri Perkembangan dan Pengarubnya Terbadap Pencapaian Akademik Siswa [On Line, Diakses tanggal 22 November 2015 dari http://www.aikesari.multiply.com

Rini, Jacinta F. 2002. Konsep Diri, diakses tanggal 30 November 2015 dari http://www.epsikologi.com. 